\title{
2021 Guidelines for Operation and Usage of County Kitchens in the State of Florida'
}

\author{
Amarat Simonne, Tim Wilson, Geralyn Sachs, Chris Hilliard, Steven von Bodungen, and Liz \\ Felter ${ }^{2}$
}

Many county Extension office buildings have small kitchens or areas for food preparation to accommodate employees, group educational events, and mission-related activities. Although the office buildings that have these kitchens were inspected and issued a certificate of occupancy by the local building department, the kitchens probably have not been permitted (or licensed) by the Florida Department of Agriculture and Consumer Services (FDACS) or licensed by the Department of Business and Professional Regulation (DBPR) or Florida Department of Health (DOH) for commercial purposes.

In recent years, many people have become interested in developing small food businesses. Using county kitchens to make food products for sale may seem very attractive. However, due to different local, state, and federal regulation requirements, there may be some confusion and unresolved conflicts among different parties as to the legalities and practicalities involved.

This publication provides guidelines for UF/IFAS Extension personnel to use when determining the appropriate usage for their kitchen facilities, based on a case study of one Florida county. The document discusses utilization, roles and responsibilities, and potential liability issues relevant to the use of county kitchens, providing some potential solutions to conflicts for all parties.

\section{Knowing the Current Usage and History of Your County Kitchen}

Do county employees use your kitchen for their breaks and lunches? Do you have more than one kitchen in your county office? If you have more than one, is there one kitchen used solely by employees and another used for events and other mission-related activities? Answers to these questions will help identify permitted activities for each facility. Single kitchens used for employee breaks and lunches must not be used to process foods for business purposes at the same time. Use of the kitchen for business purposes must be limited to hours when employees are not present. All food contact surfaces must be washed, rinsed, and sanitized prior to use.

\section{A Case Study in One Florida County}

The county Extension office kitchen in question was originally inspected by the county $\mathrm{DOH}$, but became "unregulated" in 2011 due to changes in regulation. Prior to

1. This document is FCS3338, one of a series of the Department of Family, Youth and Community Sciences, UF/IFAS Extension. Original publication date August 2016. Revised February 2021. Visit the EDIS website at https://edis.ifas.ufl.edu for the currently supported version of this publication.

2. Amarat Simonne, professor, Extension specialist, Department of Family, Youth and Community Sciences; Tim Wilson, county Extension director, Extension agent III, production agriculture; Geralyn Sachs, Extension agent III, 4-H regional specialized Extension agent, UF/IFAS Extension Central District; Chris Hilliard, chief, Bureau of Food Inspection, Florida Department of Agriculture and Consumer Services; Steven von Bodungen, director, Division of Hotels and Restaurants, Florida Department of Business and Professional Regulation; and Liz Felter, Extension agent IV, UF/IFAS Extension Central District, regional specialized agent, food systems; UF/IFAS Extension, Gainesville, FL 32611.

The Institute of Food and Agricultural Sciences (IFAS) is an Equal Opportunity Institution authorized to provide research, educational information and other services

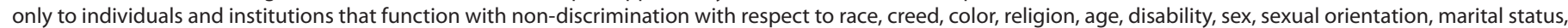

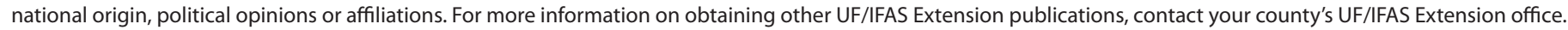
U.S. Department of Agriculture, UF/IFAS Extension Service, University of Florida, IFAS, Florida A \& M University Cooperative Extension Program, and Boards of County Commissioners Cooperating. Nick T. Place, dean for UF/IFAS Extension. 
2011, the kitchen met the minimum construction standards from the DOH. However, because there were no existing written rules or guidelines, confusion began to occur. In order to resolve these issues, various questions were addressed based on current rules and regulations.

Typical usage of kitchen (county employees, program assistants, volunteers, advisory committees or groups associated with county programs, county emergency personnel). There are no current regulations governing educational programs or demonstrations, cooking classes, or food preparation and canning classes. However, the county (i.e., risk management team or county Extension director [CED] or an appointed responsible person [supervisor], such as a county agent) should develop protocol and standard operating procedures (SOPs) to govern these uses of the facility, including some type of training in food safety for employees and other users, and recordkeeping practices for events that involve serving food. These written procedures will help reduce risk and liability for the county. The supervisor (risk management team, CED, or an appointed responsible person, such as a county agent) should be a certified food protection manager from one of the currently accredited programs in the state (National Restaurant Association Educational Foundation ServSafe ${ }^{\circledR}$, Prometric, National Registry of Food Safety Professionals, 360training. com [Learn2Serve]), or Above Training. Those who handle foods should have food handler training (FDACS, 2017; DBPR, 2018).

Other usages beyond typical usages described above. In general, using any county kitchen to produce foods for sale to the public is not allowable. In order to do commercial food operations, businesses using a county kitchen facility would need to be inspected and permitted or licensed by either DBPR or FDACS, depending on the type of food and the manner in which it will be served. (DBPR handles food for immediate consumption or mobile food service; FDACS handles packaged foods.) For more information, see the FDACS website (https://www.fdacs.gov/Business-Services/ Food-Establishments/Retail-Food-Establishment-Permit) or the DBPR website (http://www.myfloridalicense.com/ $\mathrm{dbpr} / \mathrm{hr} /$ licensing/Apply-License.html). Below are a few examples of different situations.

\section{- A private citizen wants to rent the county kitchen to} can, preserve, or prepare foods for their own personal use and not for sale or distribution. This is allowable, and they can use the kitchen in its current condition. However, it is recommended that the county consult the county attorney to develop the contract and forms. The county should develop standard operating procedures for kitchen maintenance and define clear roles and responsibilities for both the county and the user to reduce liability. In the case of canning and food preservation, the county may wish to make available the latest USDA recommendations for safe home canning.

- A private citizen wants to rent the county kitchen to make products to sell under the cottage food laws. This would not be allowed. Cottage foods must be prepared in a home. The Florida Cottage Food Law and Cottage Food Guidance documents can be found at http://www. freshfromflorida.com/content/download/70108/1634054/ Cottage_Food_Guidance.pdf.

- A private citizen wants to produce food for sale beyond the cottage food umbrella. There are two different business requirements, depending on the type of operation. For FDACS and DBPR, each county kitchen to be used to produce food for sale must meet the minimum construction standards for a processing kitchen for each agency. Information on the requirements can be found on their websites.

- Groups of people (e.g., Master Gardeners) want to produce and package foods to sell for fundraising purposes. They will still need to meet the requirements of FDACS, as indicated above. The state specialists and regulators will be able to help on a case-by-case basis.

\section{BEFORE deciding to set up an inspected kitchen for} commercial usage, here are a few things to consider:

1. Would having an inspected facility be beneficial to your county? Is there currently an inspected facility in your county for use during a natural disaster?

2. Do you have other existing inspected facilities in your county? If so, are you competing with those that pay county taxes?

3. Have you considered the effects of increased usage of the facility, such as increased water use and need for waste management? Septic tank or wells? Kitchens in offices that operate using a septic tank for sewage disposal or a well for the water supply may have additional requirements and/or restrictions. These questions need to be addressed by the Florida EPA and FDOH.

4. Do you have enough trained employees or volunteers?

5. How will this affect long-term facility maintenance?

6. Has the intention to establish an inspected kitchen for commercial usage been communicated to the county risk 
management team or integrated with the overall county operation plans?

7. Have you reviewed the minimum building requirements of FDACS/DBPR to see if any modifications are needed in the county kitchen?

Our state partners (FDACS and DBPR) are willing to assist in determining if the current usage of the county kitchens is associated with county Extension in the following ways.

- DBPR would be willing to meet with you and others regarding this venture to help strategize.

- FDACS has a voluntary plan review process to determine whether kitchens are in compliance.

- FDACS and DBPR can provide corrections for any areas that are not currently in compliance through the plan review process.

- FDACS would be willing to review business requirements for various types of food processing, such as acidified food processing.

- After consideration, if your county decides to have a commercial kitchen, contact an appropriate UF/IFAS food safety specialist for help.

\section{References}

DBPR. (2018). Food manager certification. Division of Hotels and Restaurants. Accessed on January 20, 2021. http://www.myfloridalicense.com/dbpr/HR/forms/documents/5030_080.pdf

FDACS. (2017). Certified Food Protection Manager. Division of Food Safety. Accessed on January 20, 2021. https://www.fdacs.gov/content/download/23976/file/FoodProtection-Manager-Flyers.pdf 